\title{
Rola instytucji w regionalnej gospodarce opartej na wiedzy
}

\section{The role of Institutions in the Regional Knowledge Economy}

Streszczenie: Celem artykułu była analiza wpływu instytucji na rozwój regionu w dobie gospodarki opartej na wiedzy. Instytucje funkcjonują na różnych poziomach, w odmiennych skalach i systemach. Zrozumienie ich roli w gospodarce wymaga szczegółowej specyfikacji każdego z tych elementów. $\mathrm{W}$ analizie teoretycznej autorka skupiła się na rozwoju regionalnym i innowacyjności. Jej wyniki potwierdziły trudności związane z pomiarem czynnika instytucjonalnego i ustaleniem właściwych proporcji instytucji formalnych i nieformalnych. W opracowaniu porównano koncepcje teoretyczne koncentrujące się na instytucjach i systemach jako podstawowych determinantach procesów innowacyjnych w regionach. Rezultaty potwierdziły akcentowanie w nich odmiennych elementów i mechanizmów tych procesów i tym samym zróżnicowaną rolę instytucji. Wydaje się, że najważniejszą rolę odgrywają instytucje funkcjonujące w ramach regionalnych systemów innowacji i innowacyjnych klastrów.

\begin{abstract}
The article discusses the significance of institutions in the development of a regional knowledge-based economy. Institutions are active at different arenas grouped into levels of inter-relation, scales of governance, and systems. Thus, the understanding the role of institutions requires carefully selected categories that reveal all these arenas. The theoretical analysis focuses on regional development and innovativeness. It indicates problems related to measurement of institutions and establishing the right combination of formal and informal institutions. The paper compares theoretical concepts focused on institutions and systems as the key determinants of regional innovativeness. The results show that they emphasize different elements and mechanisms of innovation processes, and thus a different role of institutions. They seem to play the most important part in regional systems of innovation and innovative clusters.
\end{abstract}

Słowa kluczowe: instytucje, innowacyjność, gospodarka regionalna, analiza teoretyczna

Key words: institutions, innovativeness, regional economy, theoretical analysis 


\section{WPROWADZENIE}

„Gospodarka oparta na wiedzy (GOW) stanowi typ gospodarki, której rozwój i przekształcenia dokonują się pod dominującym wpływem nauki. Oddziaływanie postępu naukowego staje się głównym czynnikiem rozwoju gospodarki, znacznie przeważającym nad innymi czynnikami” (Chojnicki, Czyż, 2006: 423). GOW jest zjawiskiem wielowymiarowym, które ze względu na możliwości różnorakiego doboru zmiennych i nadawania im różnej rangi, trudno jednoznacznie oszacować. Jednym z jej podstawowych elementów są innowacje. Czynnikiem niezbędnym dla jej skutecznego budowania i funkcjonowania są instytucje, które warunkują absorpcję wiedzy przez gospodarkę. Pojawienie się paradygmatu rozwoju regionalnego opartego na wiedzy nie pozostaje bez wpływu na konkurencyjność regionalną. W krótkim okresie o konkurencyjności regionu decydują takie czynniki, jak: struktura gospodarki, specjalizacja sektorowa czy jakość i gęstość infrastruktury. W perspektywie długookresowej jej poziom zależy od zdolności do utrzymania zmian czynników generujących wzrost produktywności, tj. technologii, zasobów ludzkich czy nakładów na prace badawczo-rozwojowe (Huggins, Izushi, 2008).

Założenie, że instytucje, organizacje i polityki jako endogeniczne składniki systemu gospodarczego mają wpływ na wzrost gospodarczy nie jest nowe w teorii ekonomii. Pojawia się ono między innymi w ekonomii ewolucyjnej i instytucjonalnej, dynamicznych systemach czy teorii gier. Instytucje uznawane są obecnie za istotny czynnik wzrostu gospodarczego, choć nie odzwierciedla tego liczba analiz empirycznych poświęconych temu zjawisku. Celem opracowania jest analiza teoretyczna wpływu instytucji na rozwój gospodarczy i poziom innowacyjności regionu. W pierwszej części opisano wymiary oddziaływania instytucji na gospodarkę regionu. W kolejnej części dokonano przeglądu koncepcji koncentrujących się na instytucjach i systemach jako podstawowych determinantach procesów innowacyjnych w regionach. Szczególną uwagę poświęcono klastrom i regionalnym systemom innowacji.

\section{INSTYTUCJE A ROZWÓJ GOSPODARCZY}

Teorie wyjaśniające proces wzrostu gospodarczego regionów można podzielić na dwie kontrastujące ze sobą grupy: pierwszą, wywodzącą się z ekonomii, teorię wzrostu endogenicznego oraz drugą, określaną jako „,nowy regionalizm”, skupiającą się na instytucjach i regulacjach społecznych związanych z takimi pojęciami, jak: regiony uczące się, lokalne środowisko innowacyjne, klastry, regionalne systemy innowacji, gospodarka oparta na wiedzy czy klasa kreatywna (Rainnie, Grobbelaar, 2005). Przedstawiciele drugiej grupy dowodzą, że wzrost gospodarczy nie zależy tylko od warunków rynkowych, ale również od powtarzających się interakcji zachodzących między firmami, wymiany wiedzy, kreacji kapitału społecznego i aktywności lokalnych instytucji (Golejewska, 2012a).

Związek między instytucjami a rozwojem gospodarczym był pomijany w głównych trendach teorii ekonomii, zwłaszcza w teorii wzrostu. Według neoklasycznej teorii wzrostu 
rozwój gospodarczy był wynikiem inwestycji w kapitał fizyczny (Solow, 1956). Różnice w poziomie nakładów inwestycyjnych na infrastrukturę traktowano jako podstawowy czynnik wzrostu (Aschauer, 1989). Rozwój teorii wzrostu endogenicznego wprowadził dwie nowe determinanty, mianowicie: innowacje (Romer, 1986) i edukację (Lucas, 1988). Inwestycje w infrastrukturę, edukację i szkolenia, promocja innowacji i działalności przemysłowej miały, przynajmniej w teorii, powodować wzrost gospodarczy, a ukierunkowane na regiony opóźnione - przyczyniać się do konwergencji. Trwająca trzy dekady i oparta na wspomnianych założeniach polityka regionalna przyczyniła się do zmniejszenia zróżnicowania regionalnego w takich krajach, jak: Wielka Brytania, Francja, Niemcy, Włochy, Hiszpania, Indie czy Meksyk (Rodrigez-Pose, 2010). W konsekwencji polityka rozwoju regionalnego stanowiła replikę polityki rozwoju na poziomie kraju i pomijała rolę instytucji lokalnych. Takie podejście było wynikiem z jednej strony „raczkującej” dopiero ekonomii instytucjonalnej, z drugiej testowanej i sprawdzającej się w praktyce teorii neoklasycznej i teorii wzrostu endogenicznego. Ostatnie dwie dekady doprowadziły jednak do zmiany tego podejścia. W przypadku Unii Europejskiej wynikało to przede wszystkim z faktu, że większość wyników analiz badających wpływ funduszy strukturalnych UE (po reformie w 1989 r.) na rozwój regionalny potwierdziło jego brak (Boldrin, Canova, 2001; Dall’erba, Le Gallo, 2007)ํ. Kolejnym powodem było dostrzeżenie przez ekonomistów roli instytucji i przypisanie im podobnej wagi jak tradycyjnemu wyposażeniu w czynniki, wymianie handlowej czy transferowi technologii (Hall, Jones, 1999; Acemoglu i in., 2001; Rodrik i in., 2004). Zmiany w postrzeganiu roli instytucji wprowadziła dopiero nowa ekonomia instytucjonalna, której twórcy zauważyli potrzebę umiejscowienia rynków w ich instytucjonalnym otoczeniu (Golejewska, 2013). W ekonomii instytucjonalnej, zainicjowanej przez Northa, przyjmuje się, że wzrost determinują równocześnie mechanizmy gospodarcze i aktorzy lokalni obecni na rynku (North, 1990). $\mathrm{Ci}$ ostatni wchodzą w interakcje wewnątrz i poza regionem jako jednostki indywidualne, struktury wyższego szczebla czy instytucje (Fratesi, Senn, 2009). Otoczenie instytucjonalne determinowane jest ramami administracyjnymi i prawnymi, które regulują działalność jednostek, firm i rządów (regionalnych i lokalnych). W przeciwieństwie do teorii neoklasycznej w ekonomii instytucjonalnej przyjmuje się założenie o wpływie instytucji na koszty transakcyjne i tym samym zachowania gospodarcze jednostek (Lakshmanan, Button, 2009)².

${ }^{1}$ Część analiz wykazało ograniczony lub mieszany wpływ (Bussoletti, Esposti, 2004; Puigcerver-Peñalver, 2004), jeszcze inne zróżnicowany w zależności od geograficznej lokalizacji (Percoco, 2005; Mohl, Hagen, 2008). Pozytywny wpływ potwierdziło między innymi badanie Cappelen i in., 2003. Cyt. za Rodrigez-Pose, 2010.

${ }^{2} \mathrm{Na}$ koszty transakcji składają się koszty ekonomiczne i polityczne. Autorzy nowej ekonomii instytucjonalnej dowodzą, że wielkość firmy nie tyle zależy od korzyści skali, ile od kosztów transakcyjnych związanych z komunikacją, koordynacją i podejmowaniem decyzji w przedsiębiorstwie. Ekonomiczne koszty transakcyjne można podzielić na dwie grupy: rynkowe i menadżerskie. W pierwszej wyróżnia się z kolei trzy typy kosztów: poszukiwania $\mathrm{i}$ informacji (koszty przygotowania umowy); negocjacji i podjęcia decyzji (koszty zawarcia umowy) oraz monitoringu i egzekwowania umowy. Menadżerskie koszty transakcyjne związane są z kolei z rozpoczęciem, prowadzeniem i zmianą działalności przedsiębiorstwa. Przyczyną powstania kosztów politycznych jest fakt, że ekonomiczne koszty transakcyjne mogą pojawić się tylko w kontekście uzgodnień politycznych (instytucjonalnych). Implikuje to potrzebę funkcjonowania organizacji regionalnych i krajowych oraz związanych z nimi dóbr publicznych i kosztów. Polityczne koszty transakcyjne obejmują koszty utworzenia, utrzymania oraz zmiany nieformalnych i formalnych organizacji (ramy prawne, administracja). 
Warto w tym miejscu wyjaśnić, czym są instytucje. O ile inwestycje w infrastrukturę, edukację czy innowacje są relatywnie łatwe do uchwycenia i implementacji, o tyle koncepcja instytucji jest mniej jasna, bardziej subiektywna i kontrowersyjna. Wyższy poziom inwestycji wywiera pozytywny wpływ na wzrost gospodarczy. W przypadku instytucji relacje te znacznie trudniej jest określić. Instytucje powinny ułatwiać dobrowolną i wzajemną wymianę korzyści, być „adekwatne, solidne i efektywne” (Rodrigez-Pose, 2010). Instytucje można podzielić na formalne (twarde) i nieformalne (miękkie). Pierwszą grupę tworzą uniwersalne i zbywalne reguły określone w prawie (konstytucji, zarządzeniach, statutach), drugą - normy, tradycje i zwyczaje społeczne, kontakty interpersonalne oraz nieformalne sieci powiązań, niezbędne do budowy zaufania i kapitału społecznego (Fukuyama, 2000). Amin i Thrift (1995: 100) do czynników instytucjonalnych zaliczają: nierynkowe relacje zaufania, konsensus społeczny, lokalne instytucje i organizacje wspomagające działalność gospodarczą, zwyczaje i tradycje zachęcające do przedsiębiorczości i innowacyjności, procesy tworzenia wiedzy i kształtowania umiejętności oraz obieg idei. Według Cooke’a (2001: 49) należą do nich kapitał społeczny, regulacje polityczne oraz innowacje. Porter (1985: 83, cyt. za Stachowiak, 2008: 124) podkreśla z kolei znaczenie instytucji rynku pracy wpływających na relacje między pracodawcą a pracownikiem. Autor uważa, że czynników instytucjonalnych nie należy traktować jako danych, pozostających poza kontrolą firm. Przedsiębiorstwa wpływają bowiem na instytucje przez lobbing.

Instytucje postrzegane są jako racjonalne ramy lub infrastruktura dla zarządzania współpracą między jednostkami. W tym sensie funkcjonują one jako dobro publiczne, dostępne i dzielone przez wiele jednostek. Jakość instytucji wpływa na decyzje inwestycyjne, organizację produkcji oraz decyduje o sposobach, w jakie społeczności dystrybuują korzyści wynikające z implementowanych strategii rozwoju i stosowanych polityk. Rola instytucji nie ogranicza się wyłącznie do tworzenia ram prawnych. Istotne znaczenie ma również stosunek rządu do rynków oraz efektywność działań prowadzonych przez instytucje. Rozbudowana biurokracja, przeregulowanie, korupcja, nieuczciwość przy zamówieniach publicznych, brak przejrzystości oraz niezależności systemu sądownictwa niosą wysokie koszty w przedsiębiorstwach i spowalniają proces wzrostu gospodarczego. Wymiary oddziaływania instytucji na rynek prezentuje rycina 1. Instytucje stanowią gwarancję realizacji umów i zobowiązań, rozwiązują problemy związane z prawem gospodarczym, monitorują praktyki monopolistyczne, w skrócie: tworzą korzystny klimat dla rozwoju biznesu już istniejącego w regionie i jednocześnie atrakcyjny dla firm zewnętrznych (spoza regionu). Powiązania społeczne i współpraca redukują koszty (poprawiają dostępność) informacji, szczególnie dla obecnych i potencjalnych partnerów handlowych. Prowadzą do poszerzenia potencjalnego rynku, ułatwiają identyfikację i sankcjonowanie oportunistycznych praktyk oraz przyspieszają przekazywanie informacji na temat dobrych praktyk, ułatwiając tym samym ich imitację i dyfuzję. Przyjęte zwyczaje i wspólne wartości pozwalają na podjęcie kolektywnych działań i koordynację ex ante decyzji indywidualnych, prowadzących do osiągnięcia korzyści skali i komplementarności. Z kolei wzajemne zaufanie ułatwia wymianę i zawieranie umów, kooperację (typu alianse strategiczne) oraz partnerstwo między jednostkami prywatnymi 
i publicznymi. We wszystkich tych przypadkach rola kapitału społecznego pozostaje bezsporna (Golejewska, 2013).

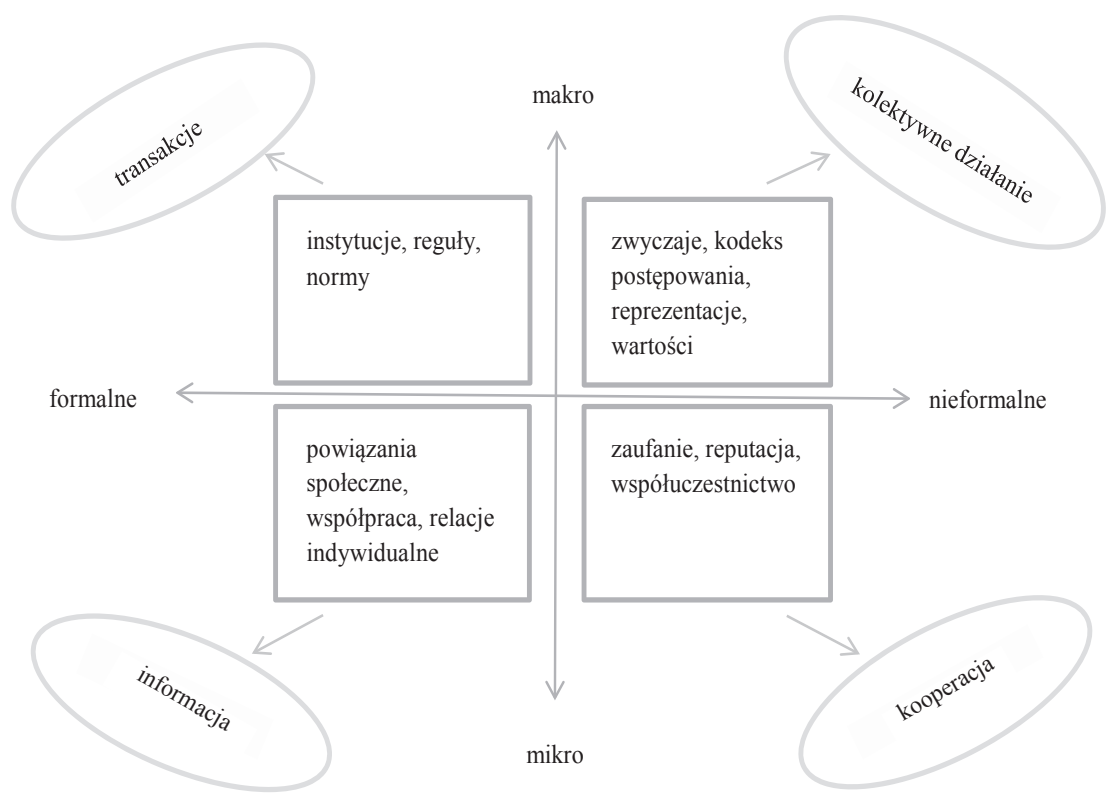

Ryc. 1. Wymiary oddziaływania instytucji na rynek

Źródło: Camagni, 2007: 42

Różne formy instytucji pozostają w stałych interakcjach, oddziałując na siebie nawzajem. Według niektórych autorów, rola instytucji miękkich i twardych w procesie rozwoju regionalnego jest zróżnicowana. Instytucje miękkie mogą stanowić substytut twardych w przypadku niesolidności, braku efektywności i zaufania społeczeństwa do tych ostatnich. Murray (2005) dowodzi, że taka sytuacja miała miejsce w krajach Europy Środkowej i Wschodniej po upadku komunizmu. Z kolei inni autorzy traktują oba rodzaje instytucji jako „równych partnerów”, nie zakładając możliwości substytucji instytucji formalnych (Rodrigez-Pose, 2010). Zgodnie z tym założeniem solidna strategia rozwoju wymaga zachowania równowagi między dwoma typami instytucji. Instytucje formalne przez minimalizację ryzyka, niepewności i korupcji tworzą dogodne warunki dla rozwoju gospodarczego (Chakravarti, 2005: 28). Instytucje nieformalne przyczyniają się z kolei do redukcji kosztów transakcyjnych, zakorzenienia się działalności gospodarczej na danym terytorium oraz wzmocnienia współzależności, a tym samym korzyści współpracy lokalnej (local economies of association).

Chociaż rola instytucji w kształtowaniu sytuacji gospodarczej kraju czy regionu nie budzi wątpliwości - przynajmniej z teoretycznego punktu widzenia - nadal brakuje spójnych analiz empirycznych w tej materii (Knack, Keefer, 1995; Mauro, 1995; Hall, Jones, 1999; Rodrik, 1999; Acemoglu i in., 2002, 2005; Rodrik i in., 2004, cyt. za Panagiotis i in., 2011). 
Rodrik (2000) podkreśla znaczenie pięciu podstawowych struktur instytucjonalnych, które nie tylko wywierają bezpośredni wpływ na wzrost gospodarczy, ale również determinują takie jego czynniki, jak: kapitał fizyczny i ludzki, decyzje inwestycyjne czy rozwój technologiczny. Należą do nich instytucje zapewniające prawa własności, opiekę socjalną, regulujące rynek, instytucje stabilizacji makroekonomicznej oraz instytucje powołane do zarządzania konfliktem społecznym (Panagiotis i in., 2011: 45). Wyniki analiz zależności między regułami społecznymi i instytucjami formalnymi a wzrostem gospodarczym wskazują na prawa własności i rządy prawa jako najważniejsze determinanty zrównoważonego wzrostu (Rodrik i in., 2004; Golejewska, 2013).

\section{INSTYTUCJE A INNOWACYJNOŚĆ REGIONÓW}

Zgodnie z podejściem systemowym, opartym na modelu interaktywnym, innowacje są rezultatem procesu, w który zaangażowanych jest wiele jednostek różnych szczebli (Wiig, Wood, 1995: 1). Interaktywny model stanowi krytykę tradycyjnego modelu linearnego, którego autorzy wskazują na działalność badawczo-rozwojową jako podstawową determinantę innowacji, a sam proces ich tworzenia określają jako „łańcuch powiązanych, następujących po sobie w określonej kolejności czynności” (formalna działalność badawczo-rozwojowa, badania stosowane, rozwój nowego produktu, komercjalizacja i innowacja). Na krytykę modelu linearnego złożyły się wyniki badań empirycznych, które nie potwierdziły roli środowisk akademickich jako jedynych źródeł impulsów i pomysłów, wskazując na pozostałe, w postaci sfery rynków i produkcji (Halvorsen, Lancave, 1998: 34). Zgodnie z interaktywnym modelem innowacji nie można jednoznacznie określić kolejności procesów, w wyniku których dochodzi do powstania innowacji. Zdolność firm do tworzenia innowacji zależy bowiem w znacznej mierze od ich powiązań z innymi firmami, instytucjami i organizacjami (Andersson, Karlsson, 2004: 6).

Innowacyjne przedsiębiorstwa mogą pozyskiwać know-how na trzy sposoby. Pierwszym z nich są zakupy na rynku, drugim zakupy dokonywane w ramach sieci powiązań - opartych na zaufaniu, wzajemnych i stabilnych relacjach rynkowych między organizacjami, i wreszcie trzecim, gdy dwa pierwsze nie zapewniają ochrony praw własności i wystarczającego zwrotu z inwestycji w nową wiedzę, stworzenie innowacji w ramach firmy. Ostatni sposób ogranicza jednak poziom różnorodności na poziomie regionalnym i prowadzi do uszczuplenia lokalnej bazy potencjalnych źródeł innowacji (Boschma, 2004). Innowacja w przedsiębiorstwie jest rezultatem oddziaływania otoczenia i zasobów wewnętrznych firmy w postaci kapitału ludzkiego, zasobów technicznych oraz działalności badawczo-rozwojowej. Czynniki zewnętrzne można podzielić na trzy grupy: otoczenie lokalne i instytucje, czynniki pozalokalne tego samego typu oraz powiązania rynkowe i sprzężenia zwrotne. W każdym przypadku rezultat oddziaływania czynników zewnętrznych zależy od zdolności absorpcyjnych firmy, silnie powiązanych z jej zasobami wewnętrznymi (Golejewska, 2012b). 
Formalne i nieformalne instytucje pomagają regionom dostosować się do zmian na rynku, wywołując swego rodzaju „sprawność adaptacyjną”, czyli chęć i zdolność lokalnych jednostek do przyswajania nowej wiedzy i angażowania się w działalność innowacyjną. Wspólna wiedza i kompetencje, które posiadają firmy, nie są elementem wystarczającym do rozpoczęcia procesu ,interaktywnego uczenia się”. Wymaga on dodatkowo uruchomienia różnych mechanizmów, takich jak rynki czy sieci powiązań, które koordynują działania w ramach i między organizacjami. Otoczenie instytucjonalne wpływa na intensywność i charakter procesu kreacji wiedzy oraz wyniki ekonomiczne firm lokalnych. Rozwój wiedzy i sieci powiązań inspiruje lokalną gospodarkę, jej przedsiębiorstwa, pracowników i instytucje do uczestnictwa w procesie „kolektywnego uczenia się” (Lawson, 2000; Golejewska, 2013). Instytucje formalne i nieformalne stanowią jeden z podstawowych kanałów wewnętrznych sieci powiązań. Umożliwiają one firmom, ich menedżerom oraz wykwalifikowanym pracownikom wymianę wiedzy i informacji dotyczących: rynku, innowacji tworzonych poza regionem oraz najlepszych praktyk. Niektóre z tych powiązań są skierowane bezpośrednio na wymianę wiedzy między uniwersytetami i sektorem biznesu, inne na tworzenie konsorcjów przedsiębiorstw oraz wspólnych projektów badawczych (Fratesi, Senn, 2009: 15). Proces dzielenia się wiedzą jest procesem społecznym, kształtowanym przez miękkie i twarde instytucje. Większość, zwłaszcza miękkich instytucji ma silny charakter regionalny. Pomimo funkcjonowania w ramach wspólnych narodowych ram instytucjonalnych, ta sama gałąź przemysłu może zachowywać się całkowicie odmiennie w dwóch różnych regionach (Gertler, 2010).

Przegląd koncepcji teoretycznych, zapoczątkowanych w latach 90. ubiegłego wieku i koncentrujących się na instytucjach i systemach jako podstawowych determinantach procesów innowacyjnych w regionach prezentuje Nowakowska (2011). Należą do nich: regiony uczące się (Storper, Florida, Aydalot, Morgan), regionalne systemy innowacji (Cooke), środowiska innowacyjne - GREMI (Aydalot, Maillat, Camagni), francuska szkoła bliskości (Rallet, Torre, Zimmermann) oraz klastry innowacyjne (Porter). W przypadku wymienionych teorii, dominującymi metodami badawczymi są wieloaspektowe analizy opisowe, charakteryzujące się znacznym subiektywizmem analitycznym. Zestawienie koncepcji przedstawiono w tabeli 1.

Przedsiębiorstwa zawdzięczają swoją innowacyjność nie tylko własnym zdolnościom organizacyjnym, ale również kontaktom z innymi przedsiębiorstwami (dostawcami, kontrahentami) oraz instytucjami (Golejewska, 2012c). Już od dawna autorzy prac z zakresu geografii ekonomicznej podkreślają, że ze względu na milczący charakter wiedzy (umiejętności, rutyna) $)^{3}$, wspomniany typ interakcji zachodzi często na poziomie lokalnym, między organizacjami bliskimi geograficznie (Storper, Venables, 2004; Asheim, Gertler, 2005; Boschma, 2005). Komunikacja, współpraca i koordynacja stanowią obecnie niezbędne warunki do tworzenia i dyfuzji technologii w regionie (Golejewska, 2012b). Szczególną rolę w tym procesie odgrywają instytucje funkcjonujące w ramach regionalnych systemów innowacji, którym poświęcona została kolejna, odrębna część opracowania.

${ }^{3}$ Wiedza milcząca (niejawna) określana jest jako wiedza cicha, bezwiedna, niezwerbalizowana (Leonard, Sensiper, 1998). Jest to wiedza personalna, którą trudno wyartykułować i/lub przekazać. Przykładem może być wiedza ekspertów z danej dziedziny i problem z werbalizacją swoich doświadczeń. 
Tab. 1. Procesy innowacji w teoriach skoncentrowanych na instytucjach i systemach

\begin{tabular}{|c|c|}
\hline $\begin{array}{c}\text { Główne } \\
\text { szkoły/nurty } \\
\text { myśli } \\
\text { ekonomicznej }\end{array}$ & Podstawowe założenia \\
\hline $\begin{array}{l}\text { Regiony } \\
\text { uczące się }\end{array}$ & $\begin{array}{l}\text { Twórcą paradygmatu regionu uczącego się jest Florida, choć zasadniczy udział } \\
\text { w jego tworzeniu mieli również inni autorzy: Aydalot, Camagni i Maillat. Jego } \\
\text { koncepcja wywodzi się między innymi z teorii systemów innowacji, postfordyzmu, } \\
\text { czy teorii klastrów. } \\
\text { Regiony uczące się oznaczają miejsca, w których dochodzi do interakcji } \\
\text { stymulujących procesy zbiorowego (kolektywnego) uczenia się (Benneworth, } \\
\text { Rutten, 2011: 7). Podstawową kwestią koncepcji są mechanizmy uczenia się: } \\
\text { interaktywnego, instytucjonalnego, organizacyjnego i uczenia przez uczenie } \\
\text { (Golińska-Pieszyńska, 2009). Procesom uczenia się towarzyszą procesy innowacji } \\
\text { i terytorializacji. Opisane zjawiska zachodzą nie tylko w obrębie regionu, ale } \\
\text { „rozlewają się” również przez relacje, jakie region utrzymuje z gospodarką globalną } \\
\text { (Morgan, 2007). Region uczący się jest konkurencyjny, ponieważ konkurencyjne } \\
\text { jest całe terytorium w stosunku do otoczenia. Konkurencyjność regionu determinuje } \\
\text { infrastruktura wiedzy oraz infrastruktura instytucjonalna zapewniająca dostęp do } \\
\text { wiedzy formalnej i niekodyfikowanej (Nowakowska, 2011). Koncepcja regionu } \\
\text { uczącego się krytykowana jest z kilku powodów. Do najważniejszych należą: } \\
\text { brak wyraźnych założeń; normatywność (region uczący się jako jedyny wzorzec } \\
\text { „regionu sukcesu”); podobieństwo do koncepcji regionalnych systemów innowacji } \\
\text { i środowiska innowacyjnego oraz umiejscowienie koncepcji regionu uczącego się } \\
\text { między narodowym systemem innowacji (krajowa polityka badawczo-rozwojowa) } \\
\text { i globalnymi sieciami powiązań (transnarodowe systemy innowacji, Benneworth, } \\
\text { Rutten, 2011). }\end{array}$ \\
\hline $\begin{array}{l}\text { Klastry } \\
\text { innowacyjne }\end{array}$ & $\begin{array}{l}\text { W literaturze przedmiotu istnieje wiele definicji klastrów (gron, wiązek } \\
\text { przemysłowych, z fr., lokalnych systemów produkcyjnych). Zgodnie z definicją } \\
\text { Portera (1998: 197-198) klastry oznaczają ,geograficzną koncentrację wzajemnie } \\
\text { powiązanych specjalistycznych firm wytwórczych, dostawców usług i zaopatrzenia, } \\
\text { kooperantów oraz instytucji otoczenia biznesu (uniwersytetów, agencji, organizacji } \\
\text { handlowych), które ze sobą jednocześnie konkurują i kooperują”. Opierając się na } \\
\text { wynikach licznych badań empirycznych, autor dowodzi, że konkurencyjne branże } \\
\text { przemysłowe wykazują stałą skłonność do tworzenia skupisk geograficznych } \\
\text { w ramach wybranych regionów (Porter 2003). Jedną z przyczyn budowy klastrów } \\
\text { jest ułatwienie firmom tworzącym je szybkiego dostępu do nowych technologii } \\
\text { i informacji w zakresie jej zmian (Oerlemans i in., 2001). Klaster innowacyjny } \\
\text { (badawczy, oparty na wiedzy) od klasycznej formy współpracy odróżnia: } \\
\text { - branża, w której funkcjonują, najczęściej wysokich technologii (klastry mogą } \\
\text { jednak powstawać w sektorach uznawanych powszechnie za nisko innowacyjne } \\
\text { jak przemysł spożywczy czy budownictwo), } \\
\text { - struktura podmiotów, w której pierwszoplanową rolę odgrywa sektor naukowo- } \\
\text {-badawczy wspierany przez instytucje otoczenia biznesu, } \\
\text { - cel działania klastra zorientowany na generowanie innowacji i transfer technologii. } \\
\text { Istotną rolę w klastrach wiedzy odgrywają bezpośrednie, często nieformalne relacje } \\
\text { niehandlowe opierające się na wymianie informacji rynkowych i wiedzy milczącej. }\end{array}$ \\
\hline
\end{tabular}




\begin{tabular}{|c|c|}
\hline & $\begin{array}{l}\text { W skład klastra innowacyjnego wchodzą: jednostki badawcze, uczelnie wyższe, } \\
\text { innowacyjne przedsiębiorstwa, instytucje wspierające proces innowacji (parki } \\
\text { naukowo-technologiczne, centra transferu technologii) oraz przedsiębiorstwa } \\
\text { przemysłowe i usługowe, których działalność nie wymaga, przynajmniej } \\
\text { bezpośrednio, badań i rozwoju. Tworzą go również inne podmioty lokalne: izby } \\
\text { gospodarcze i przemysłowo-handlowe czy instytucje finansowe. Koncepcja klastrów } \\
\text { innowacyjnych podkreśla znaczenie władz publicznych i instytucji formalnych } \\
\text { (banków, aniołów biznesu, firm prawniczych, instytucji kontrolnych itp.), } \\
\text { które wpływają na powstanie, funkcjonowanie i kierunki rozwoju klastra. } \\
\text { Instytucjonalny kontekst funkcjonowania klastrów wiedzy wykazuje znaczne } \\
\text { różnice w poszczególnych krajach i regionach, co w istotny sposób wpływa na } \\
\text { dynamikę procesów innowacji (Nowakowska, 2011). }\end{array}$ \\
\hline $\begin{array}{l}\text { Regionalne } \\
\text { systemy } \\
\text { innowacji }\end{array}$ & 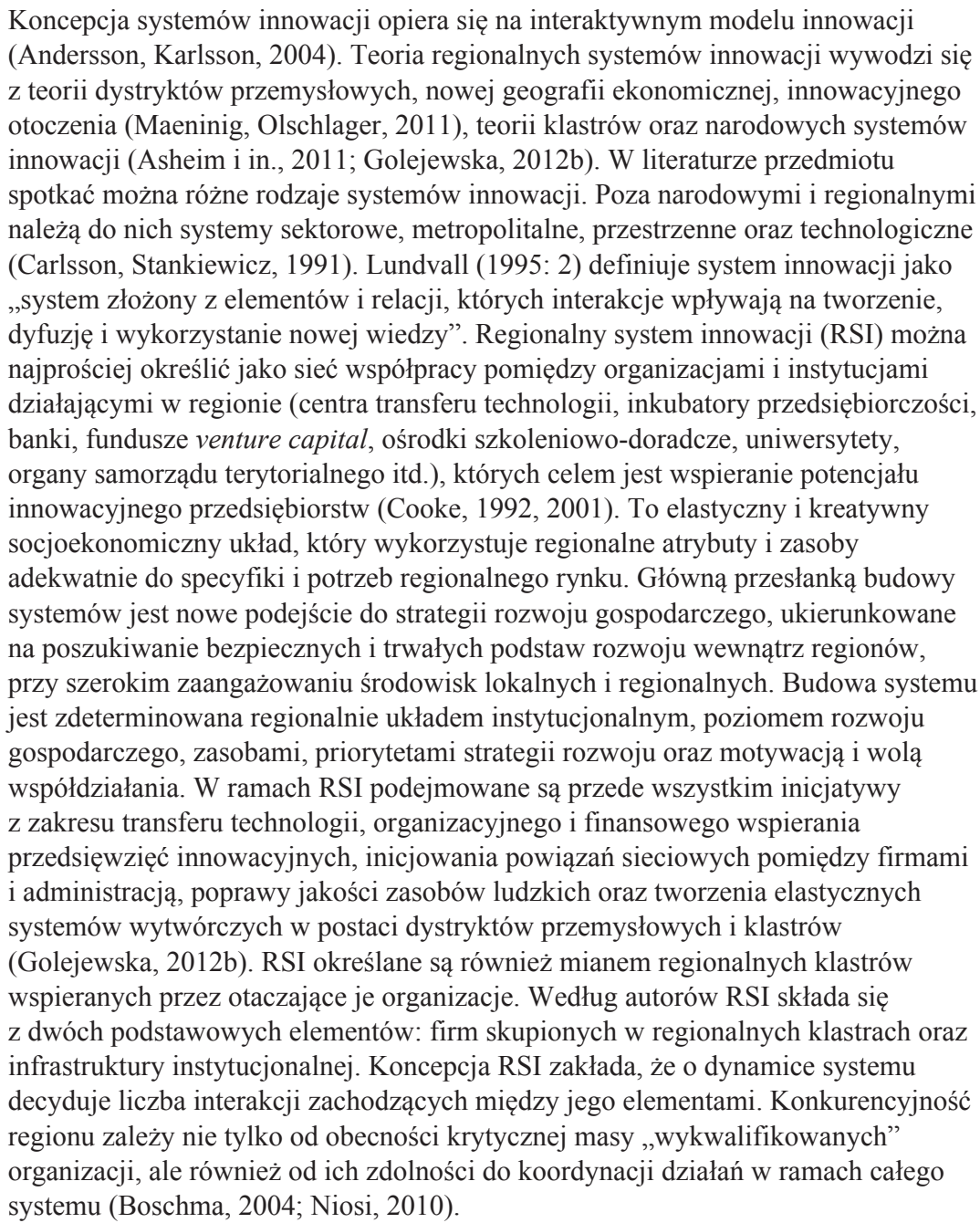 \\
\hline
\end{tabular}




\begin{tabular}{|c|c|}
\hline $\begin{array}{l}\text { Środowiska } \\
\text { innowacyjne } \\
\text { - GREMI } \\
\text { (innovative } \\
\text { milieu) }\end{array}$ & 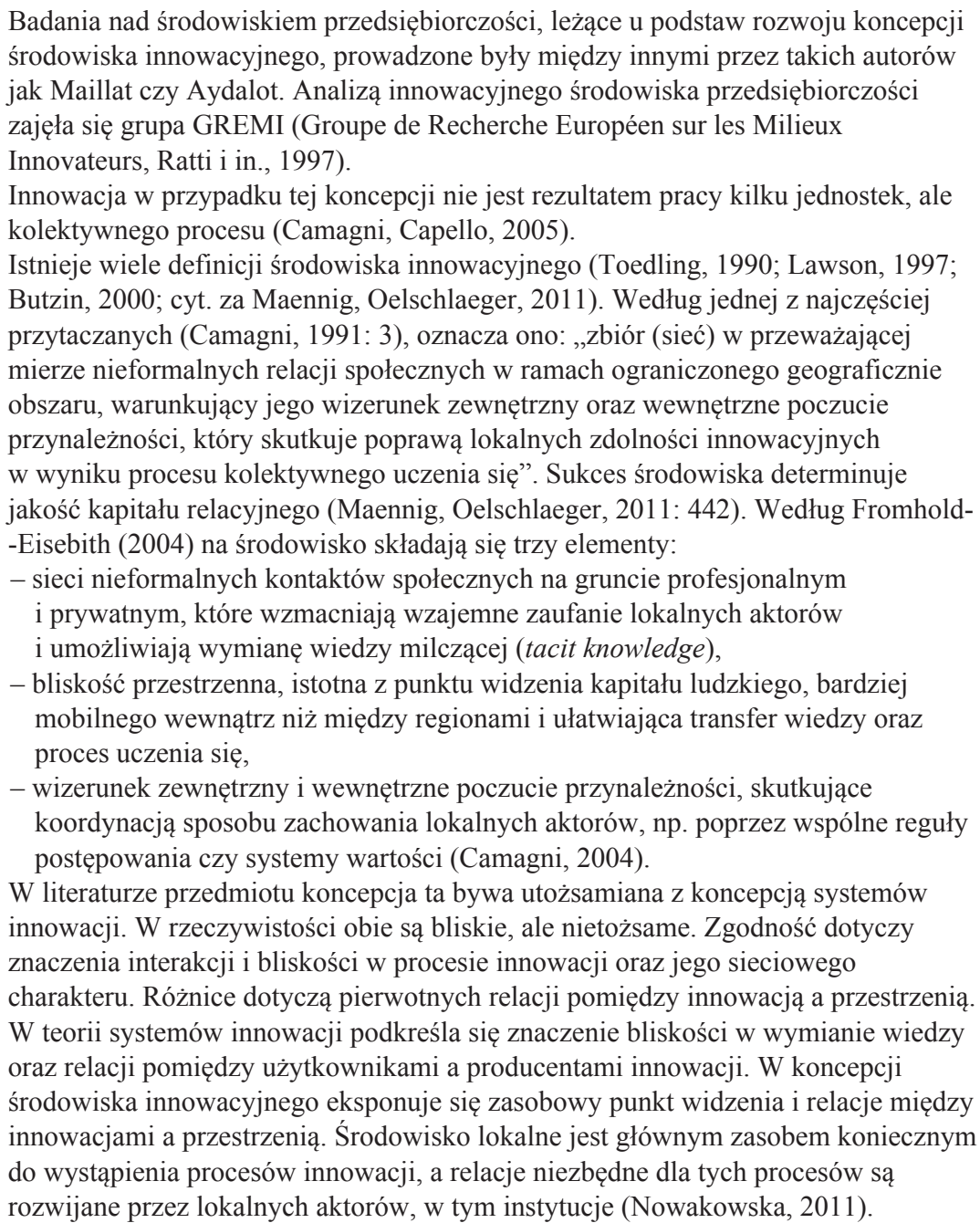 \\
\hline $\begin{array}{l}\text { Francuska } \\
\text { szkoła } \\
\text { bliskości }\end{array}$ & $\begin{array}{l}\text { Paradygmat bliskości, traktowany jako pochodna trzech nurtów teoretycznych: } \\
\text { środowiska innowacyjnego, dystryktu przemysłowego i nowej geografii } \\
\text { ekonomicznej, stara się wyjaśnić rolę bliskości w kształtowaniu relacji między } \\
\text { różnymi aktorami lokalnymi. Bliskość interpretowana jest zarówno w wymiarze } \\
\text { geograficznym, jak i organizacyjnym (skłonność podmiotów do inicjowania } \\
\text { wspólnych przedsięwzięć). U podstaw tej koncepcji leżą trzy elementy: bliskość, } \\
\text { interakcja i koordynacja. Jednostki tworzą system relacji społecznych, który opisuje } \\
\text { ramy interakcji oraz system instytucji określający reguły gry i zasady postępowania. } \\
\text { Wyróżnić można pięć rodzajów bliskości: poznawczą, organizacyjną, społeczną, } \\
\text { instytucjonalną i geograficzną (Rallet, Torre, 2007; Pecqueur, Zimmermann, 2004). } \\
\text { Pierwszy oznacza zdolność podmiotów do uczenia się nawzajem i przyswajania od } \\
\text { siebie nowej wiedzy, umiejętność komunikowania się, rozumienia i przetwarzania } \\
\text { wiedzy. Brak bazowego zasobu wiedzy, tzw. luka wiedzy, uniemożliwia wspólne }\end{array}$ \\
\hline
\end{tabular}




projekty innowacyjne. Z kolei zbyt dużo bliskości poznawczej może powodować
ograniczenie procesów interaktywnego uczenia się. Bliskość organizacyjna to
zdolność organizacji (firmy, jednostki administracyjnej, sieci, społeczności,
środowiska itp.) do współdziałania. Bliskość organizacyjna redukuje niepewność,
ryzyko i oportunizm towarzyszące procesom kreacji wiedzy i innowacji. Jej nadmiar
wiąże się z kolei z ryzykiem zamknięcia się podmiotów na swoje otoczenie,
ograniczeniem dostępu do nowych źródeł informacji i wiedzy i ograniczeniem
poszukiwania nowych kanałów ich wymiany. Bliskość społeczna określana jest
często mianem ,zakorzenienia” podmiotów gospodarczych. Więzi społeczne,
przyjaźń czy lojalność prowadzą do lepszych wyników ekonomicznych, są
warunkiem wstępnym procesu interaktywnego uczenia się i tworzenia innowacji.
Zdolność do innowacji może jednak słabnąć wraz z „,zakorzenieniem”. Może
bowiem dojść do „przeciążenia” zaufaniem i ograniczenia postaw konkurencyjnych,
co przejawia się rezygnacją z działań proinnowacyjnych oraz osłabieniem motywacji
do uczenia się. Sprawnie funkcjonujące otoczenie instytucjonalne redukuje z kolei
niepewność rynkową poszczególnych podmiotów, co w konsekwencji wywiera
istotny wpływ na procesy uczenia się, innowacji i transferu technologii. Nadmiar
tego typu bliskości może okazać się niekorzystny dla innowacji z powodu „bierności
i bezwładu” instytucjonalnego. Bliskość geograficzna rozumiana jako dystans
przestrzenny jest źródłem bezpośrednich kontaktów i wzmacnia intensywność
oraz gęstość relacji zachodzących pomiędzy podmiotami. Nie jest warunkiem
koniecznym do wymiany wiedzy, ale ją ułatwia. W rzeczywistości, wymienione
formy bliskości są powiązane i wzajemnie się uzupełniają (Nowakowska, 2011).

Źródło: opracowanie własne na podstawie źródeł cytowanych w tabeli

\section{REGIONALNE SYSTEMY INNOWACJI, KLASTRY I GĘSTOŚĆ INSTYTUCJONALNA}

Na początku warto zastanowić się, czy każdy klaster można określić jako RSI. Nawet jeśli klaster odgrywa istotną rolę w systemie innowacji, trudno na nie odpowiedzieć twierdząco, istnienie regionalnego klastra nie jest bowiem wystarczającym warunkiem funkcjonowania systemu. Według Cooke’a (Cooke i in., 1997: 484), RSI musi spełniać określone wymogi. W skład innowacyjnego klastra wchodzą: firmy, które posiadają dostęp do innych przedsiębiorstw określonego (swojego) sektora jako klienci, dostawcy lub partnerzy w ramach formalnych i nieformalnych sieci współpracy; centra wiedzy w postaci uniwersytetów, ośrodków badawczych czy agencji transferu technologii o istotnym znaczeniu dla sektora; oraz struktura złożona z prywatnych stowarzyszeń biznesu, izb handlowych, publicznych agencji rozwoju gospodarczego i promocji oraz ministerstw. Jeśli w ramach tak zdefiniowanego systemu istnieje regularna i dwustronna wymiana informacji z zakresu innowacji, mówimy o „uczącym się” systemie regionalnym (regional learning system). Jeśli uzupełnimy go o strukturę finansową, umożliwiającą firmom pozyskiwanie funduszy na inwestycje skutkujące innowacjami, możemy określić go mianem regionalnego systemu innowacji. Klastry stanowią strukturę przemysłową, na której opiera się RSI. Nie każdy RSI można 
jednak uznać za kompletny. Rycina 2 przedstawia elementy kompletnego systemu, którego rdzeń stanowią firmy działające w ramach klastra, otoczone innymi współpracującymi z nimi przedsiębiorstwami. Instytucje w postaci struktur normatywnych i „reguł gry” ułatwiają kooperację oraz transfer i dyfuzję wiedzy. Dochodzi do powstania współzależności. Firmy otacza również infrastruktura wiedzy i technologii oraz infrastruktura finansowa.

Rycina 2 sugeruje, że podstawową rolę w funkcjonowaniu RSI odgrywają relacje na linii uniwersytet - przemysł - rząd. Potwierdza to teoria potrójnej helisy (Triple Helix Theory, Etzkowitz, 2003; Etzkowitz, Leydesdorff, 2000), według której działalność innowacyjna jest produktem współpracy trzech typów instytucji - jednostek sektora nauki, organów administracji rządowej i przedsiębiorstw sektora prywatnego. Szczególnie istotne są tu powiązania między organami administracji lokalnej i regionalnej oraz sektorem nauki.

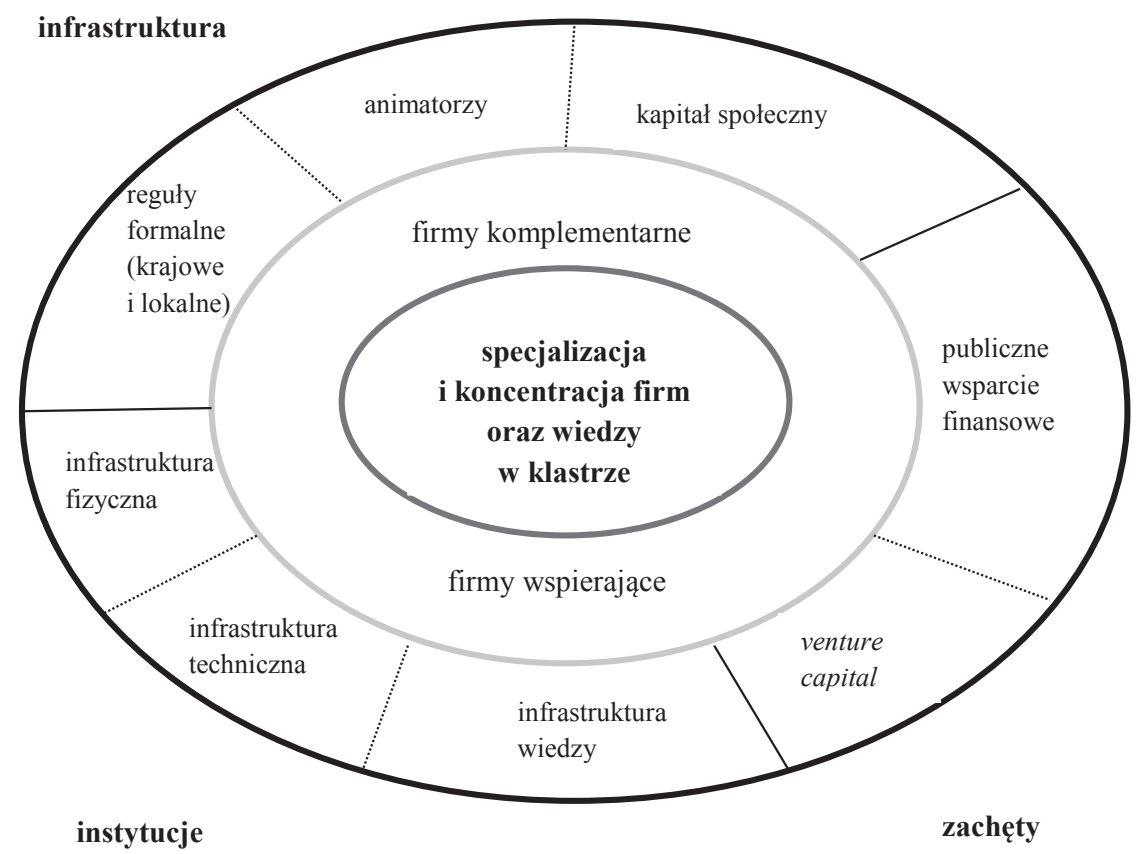

Ryc. 2. Kompletny regionalny system innowacji

Źródło: Andersson, Karlsson, 2004: 12

Obok uniwersytetów infrastrukturę wiedzy tworzą również pozauniwersyteckie instytuty badawcze. Koschatzky (2001: 3) podkreśla, że wyższe instytuty badawcze (Higher Research Institutes) powinny pełnić dwie podstawowe funkcje w regionie:

1. Tworzyć wspólną bazę wiedzy przez edukację, dystrybucję informacji z zakresu nauki i technologii oraz transfer rozwiązań technologicznych.

2. Dostarczać wiedzę ekspercką przez trening, konsultacje i transfer usług.

Według autora, instytuty badawcze nie tylko dostarczają wiedzę, ale są również inkubatorami dla nowych firm. Pomagają w komercjalizacji innowacyjnych produktów 
i tworzeniu nowych przedsiębiorstw. Ich obecność stanowi istotny czynnik atrakcyjności inwestycyjnej regionu.

Miernik czynnika instytucjonalnego w regionie stanowi gęstość instytucjonalna. Definiowana jest ona jako kombinacja następujących elementów (Amin, Thrift, 1995): silnej infrastruktury organizacyjnej, wysokiego poziomu interakcji, kultury zbiorowej reprezentacji oraz dzielonych norm i wartości, które służą budowie społecznej tożsamości regionu. Niska gęstość instytucjonalna dotyczy regionów słabiej zurbanizowanych, zdominowanych przez MŚP o ograniczonych możliwościach innowacyjnych, które cechuje brak organizacji wspierających rozwój biznesu i niski stopień aglomeracji. Regiony charakteryzujące się wysoką gęstością instytucjonalną to najczęściej obszary metropolitalne, o gęstej sieci instytucji wsparcia biznesu i wysokim poziomie innowacyjności. Gęstość instytucjonalna warunkuje aktywność regionów w ramach globalnych, krajowych i regionalnych sieci współpracy. W przypadku niskiej gęstości instytucjonalnej częściej nawiązywana jest współpraca na poziomie krajowym lub regionalnym. Wysoka gęstość sprzyja z kolei kooperacji w ramach sieci międzynarodowych (Chaminade, 2011: 6-7). Kolejną kwestią związaną z gęstością instytucjonalną jest jej wpływ na wewnątrzfirmowe (intra-firm innovation networks) i międzyorganizacyjne sieci innowacji (inter-organizational innovation networks). Analiza pierwszego typu sieci skupia się na indywidualnych pracownikach przedsiębiorstwa, a jej celem jest określenie wpływu struktury i kultury organizacyjnej na ich kreatywność i w konsekwencji innowacyjność firmy (Amabile, 1988; Ibarra, 1993; Perry-Smith, 2003). Drugi typ analiz bada rolę systemów innowacji (Kastelle, Potts i in., 2009). Większość analiz teoretycznych i empirycznych dotyczy drugiego typu sieci (Liu, 2011: 4). Trudno określić, w którym z omawianych typów sieci innowacji instytucje odgrywają większą rolę, brakuje bowiem analiz porównawczych w tym zakresie. Liu (2011: 22) dowodzi, że gęstość instytucjonalna ma pozytywny wpływ na zewnętrzne organizacje współpracujące w przedsiębiorstwami w zakresie działalności innowacyjnej, czego nie można zaobserwować w przypadku sieci wewnątrzfirmowych.

Chociaż rola instytucji w regionalnych systemach innowacji jest bezsporna, liczba analiz poświęconych temu zagadnieniu pozostaje nadal niewielka (między innymi Doloreux, Parto, 2005; Amin, Thrift, 1994, 1996; Cooke, Gomez-Uranga i in., 1997; Asheim, Isaksen, 2002; Morgan, 2007; Gertler, 2010; cyt. za Chaminade, 2011). Dreger i Erber (2010) prezentują rolę instytucji w procesie dyfuzji wiedzy na przykładach regionalnych systemów innowacyjnych Auditory Valley w Niemczech i Zhongguan-cun Science Park w Chinach. Autorzy podkreślają znaczenie kreacji środowiska innowacji, na które składa się nie tylko infrastruktura wsparcia innowacji w biznesie, ale również transfer wiedzy do sektora produkcji. Porównania dwóch wiodących regionalnych systemów innowacji we Wschodnich (Drezno i Jena) i Zachodnich Niemczech (Aachen i Karlsruhe) dokonali Fritsch i Graf (2011). Wyniki ich analizy potwierdziły niższą jakość powiązań kooperacyjnych między lokalnymi aktorami w Niemczech Wschodnich. Odmienną rolę instytucji w regionalnych systemach innowacji Badenii Wirtembergii i Walii prezentuje Cooke (2001: 954-958). Pierwszy system autor określa mianem heterarchicznego, charakteryzującego się podziałem kompetencji między lokalnych aktorów, drugi - częściej spotykanego systemu hierarchicznego. 


\section{Podsumowanie}

Literatura przedmiotu wskazuje na istotną rolę czynników instytucjonalnych w rozwoju gospodarki opartej na wiedzy, w szczególności ich wpływ na innowacyjność. Działalność innowacyjna coraz rzadziej zamyka się w ramach pojedynczej firmy i coraz częściej wymaga prowadzenia wspólnych działań. Poziom innowacyjności regionów wzrasta, jeśli firmy skutecznie zachęcane są do interakcji z instytucjami i innymi przedsiębiorstwami w regionie. Instytucje warunkują aktywność regionów w ramach globalnych, krajowych i regionalnych sieci współpracy. Infrastruktura wiedzy i systemy jej transferu wraz z indywidualnymi strategiami firm stanowią istotne stymulanty działalności innowacyjnej.

W przedstawionych koncepcjach teoretycznych koncentrujących się na instytucjach i systemach jako podstawowych determinantach procesów innowacyjnych w regionach, akcentowane są wybrane elementy i mechanizmy tych procesów. W regionalnym systemie innowacji i regionie uczącym się za podstawę tworzenia innowacji uznaje się interakcje, które prowadzą do procesów interaktywnego uczenia się i w konsekwencji powstania innowacji. Podobnie jak w przypadku innowacyjnych klastrów istotną rolę odgrywają tu instytucje publiczne i polityka regionalna. To, co najbardziej różni analizowane koncepcje, to charakter procesu innowacji: od społeczno-kulturowego kontekstu w środowisku innowacyjnym po wynik aktywności badawczo-rozwojowej w innowacyjnych klastrach (Nowakowska, 2011).

Analiza roli instytucji wymaga odniesienia do poziomu, skali i systemów, w ramach których działają. Instytucje to zintegrowana sieć powiązań funkcjonująca w różnych systemach ekonomicznych i społecznych, w skali lokalnej, regionalnej i krajowej, na poziomie jednostek, organizacji i całego społeczeństwa. Badania instytucjonalne wymagają specyfikacji każdego z tych elementów. Tylko takie bowiem podejście umożliwia koncentrację na najważniejszych instytucjach i eliminuje holistyczne podejście do zakresu badawczego. Endogeniczny rozwój regionu wymaga interwencji publicznych, stymulujących rozwój klastrów czy sieci powiązań. Regionalne polityki innowacji można podzielić na dwa typy: zorientowane na firmy lub systemy. Celem pierwszego typu polityki jest poprawa dostępu do kapitału: ludzkiego (np. poprzez doradztwo), finansowego (pożyczki, subsydia) czy fizycznego (inkubatory, centra badawczo-technologiczne). W przypadku drugiego typu wsparciu podlegają sieci powiązań, klastry, regionalne systemy innowacji, tworzenie kultury innowacji oraz kooperacja. Oba typy polityk mogą funkcjonować równocześnie, pod warunkiem ich skutecznej koordynacji (Nauwelaers, Wintjes, 2003). Znalezienie jednego, najlepszego wzorca polityki regionalnej, który odpowiadałby zróżnicowanym potrzebom wszystkich regionów, jest raczej niemożliwe. Brakuje bowiem optymalnego modelu rozwoju regionalnego, który dałoby się w sposób uniwersalny implikować w każdym środowisku lokalnym. Zadaniem polityków nie powinna być imitacja instytucjonalnych modeli rozwoju regionów, typu Dolina Krzemowa, bez uwzględnienia kontekstu specyficznego dla danego regionu. Podstawowym problemem polityki regionalnej w zakresie imitacji najlepszych praktyk są, często subtelne, współzależności występujące między różnymi elementami „optymalnego modelu”. Ograniczenia dotyczą nie tylko całych modeli, jak wspomniany model Doliny 
Krzemowej, ale również ich elementów w postaci omówionych w opracowaniu systemów innowacji (Boschma, 2004; Golejewska, 2013).

\section{Literatura}

Acemoglu, D., Johnson, S., Robinson, J.A. (2001). The Colonial Origins of Comparative Development: An Empirical Investigation. American Economic Review, 91(5), 1369-1401.

Amabile, T.M. (1988). A Mode of Creativity and Innovation in Organisations. Research in Organizational Behaviour, 10(1), 123-167.

Amin, A., Thrift, N.J. (1995). Globalisation, Institutional Thickness and The Local Economy. W: P. Healey, S. Cameron, S. Davoudi, S. Graham, A. Madinpour (ed.), Managing Cities: The New Urban Context. Chichester: Wiley.

Andersson, M., Karlsson, Ch. (2004). Regional Innovation Systems in Small \& Medium-Sized Regions. A Critical Review \& Assessment. CESIS Electronic Working Paper Series, 10.

Aschauer, D.A. (1989). Is Public Expenditure Productive? Journal of Monetary Economics, 23(2), 177-200.

Asheim, B., Smith, H.L., Oughton, Ch. (2011). Regional Innovation Systems: Theory, Empirics and Policy. Regional Studies, 45(7), 875-891.

Asheim, B., Gertler, M. (2005). The Geography of Innovation: Regional Innovation Systems. W: J. Fagerberg, D. Movery, R. Nelson, The Oxford Handbook of Innovation, Oxford: Oxford University Press.

Benneworth, P., Rutten, R. (2011). Territorial Innovation Models Beyond the Learning Regions Towards Understanding the Social Dynamics of Innovation Networks. Paper presented to $16^{\text {th }}$ International Conference of the Regional Studies Association, Newcastle upon Tyne, United Kingdom, $18^{\text {th }}-20^{\text {th }}$ April.

Boldrin, M., Canova, F. (2001). Inequality and Convergence in Europe's Regions: Reconsidering European Regional Policies. Economic Policy, 16, 207-253.

Boschma, R.A. (2004). The Competitiveness of Regions from an Evolutionary Perspective. Regional Studies, 38 (9), 1001-1014.

Boschma, R.A. (2005). Proximity and Innovation: a Critical Assessment. Regional Studies, 39(1), 61-74.

Camagni, R. (1991). Introduction: From the Local 'Milieu' to Innovation through Cooperative Networks. W: R. Camagni (ed.), Innovation Networks: Spatial Perspectives. London: Belhaven.

Camagni, R. (2004). Uncertainty, Social Capital and Community Governance: The City as a Milieu. W: R. Capello, P. Nijkamp (ed.), Urban Dynamics and Growth - Advances in Urban Economics. Amsterdam: Elsevier.

Camagni, R. (2007). Regional Competitiveness: Towards a Concept of Territorial Capital. W: R. Capello (red.), Modelling Regional Scenarios for the Enlarged Europe: European Competiveness and Global Strategies. Imprint Berlin-London: Springer.

Camagni, R., Capello, R. (2005). Urban Milieu: From Theory to Empirical Findings. W: R.A. Boschma, R.C. Kloostermann (ed.), Learning from Clusters - A Critical Assessment from an Economic-Geographical Perspective. Dordrecht: Springer.

Carlsson, B., Stankiewicz, R. (1991). On the Nature, Function, and Composition of Technological Systems. Journal of Evolutionary Economics, 1(2), 93-118.

Chakravarti, A. (2005). Aid, Institutions and Development. Aldershot: Edward Elgar.

Chaminade, C. (2011). Exploring the Role of Regional Innovation Systems and Institutions in Global Innovation Networks. CIRCLE Paper, 15.

Chojnicki, Z., Czyż, T. (2006). Aspekty regionalne gospodarki opartej na wiedzy w Polsce. Poznań: Bogucki Wydawnictwo Naukowe. 
Cooke, P. (1992). Regional Innovation Systems: Competitive Regulation in the New Europe. Geoforum, 23(3), 365-382.

Cooke, P. (2001). Regional Innovation Systems, Clusters, and the Knowledge Economy. Industrial and Corporate Change, 10 (4).

Cooke, P., Uranga, M.J., Etxebarria, G. (1997). Regional Innovation Systems: Institutional and Organizational Dimensions. Research Policy, 26, 475-491.

Dall'erba, S., Le Gallo, J. (2007). Regional Convergence and the Impact of European Structural Funds 1989-1999: A Spatial Econometric Analysis. Working Paper of the Department of Geography and Regional Development of the University of Arizona, 01-07.

Dreger, C., Erber, G. (2010). The Design of Regional Innovation Systems. Working Papers IAREG, $6(01)$.

Etzkowitz, H. (2003). Innovation in Innovation: The Triple Helix of University-Industry-Government Relations. Social Science Information, 42, 293-337.

Etzkowitz, H., Leydesdorff, L. (2000). The Dynamics of Innovation: From National Systems and Mode 2 to a Triple Helix of University-Industry-Government Relations. Research Policy, 29, $109-123$.

Fratesi, U., Senn, L. (2009). Regional Growth, Connections and Economic Modelling: An Introduction. W: U. Fratesi, L. Senn (ed.), Growth and Innovation of Competitive Regions. The Role of Internal and External Connections. Berlin Heidelberg: Springer Verlag.

Fritsch, M., Graf, H. (2011). How Sub-national Conditions Affect Regional Innovation Systems: The Case of the Two Germanys. Papers in Regional Science, 90 (2).

Fromhold-Eisebith, M. (2004). Innovative Milieu and Social Capital - Complementary or Redundant Concepts of Collaboration Based Regional Development? European Planning Studies, 12, $747-765$.

Fukuyama, F. (2000). Social Capital and the Civil Society. IMF Working Paper, 74.

Gertler, M.S. (2010). Rules of the Game: The Place of Institutions in Regional Economic Change. Regional Studies, 44(1), 1-15.

Golejewska, A. (2012a). Rozwój regionalny w warunkach transformacji gospodarczej. Wybrane aspekty konkurencyjności regionów Grupy Wyszehradzkiej. W: A. Zielińska-Głębocka, K. Gawlikowska-Hueckel (red.), Konkurencyjność międzynarodowa i regionalna państw Grupy Wyszehradzkiej: Polski, Wegier, Czech i Słowacji. Gdańsk: Wydawnictwo Uniwersytetu Gdańskiego, 187-236.

Golejewska, A. (2012b). Innowacyjność a konkurencyjność regionalna krajów Grupy Wyszehradzkiej w latach 1999-2008. Prace Komisji Geografii Przemystu Polskiego Towarzystwa Geograficznego, 19.

Golejewska, A. (2012c). Konkurencyjność regionów wiedzy i ich lokalizacja w krajach Grupy Wyszehradzkiej. W: E. Molendowski (red.), Globalizacja i regionalizacja we wspótczesnym świecie. Księga jubileuszowa poświęcona Profesor Irenie Pietrzyk. Kraków: Wydawnictwo UEK, 123-135.

Golejewska, A. (2013). Kapitał ludzki, innowacje i instytucje a konkurencyjność regionów Europy Środkowej i Wschodniej. Zeszyty Natolińskie, 49.

Golińska-Pieszyńska, M. (2009). Polityka wiedzy a współczesne procesy innowacyjne. Warszawa: Wydawnictwo Naukowe Scholar.

Hall, R.E., Jones, C.I. (1999). Why Do Some Countries Produce So Much More Output per Worker than Others? Quarterly Journal of Economics, 114 (1), 83-116.

Halvorsen, K., Lacave, M. (1998). Innovation Systems in Urban Areas. NIBR Working Paper, 110.

Huggins, R., Izushi, H. (2008). Benchmarking the Knowledge Competitiveness of the Globe's High Performing Regions: A Review of the World Knowledge Competitiveness Index. Competitiveness Review, 18 (1/2), 70-86.

Ibarra, H. (1993). Network Centrality, Power, and Innovation Involvement: Determinants of Technical and Administrative Roles. Academy of Management Journal, 36(3), 471-501. 
Kastelle, T., Potts, J. (2009). The Evolution of Innovation Systems. DRUID Summer Conference 2009, Copenhagen.

Koschatzky, K. (2001). Regional Development through Entrepreneurship Promotion? The Role of Higher Education Institutes for Stimulating Firm Foundations. Paper presented at the $41^{\text {st }}$ Congress of the ERSA, Zagreb, Croatia.

Lakshmanan, T.R., Button, K.J. (2009). Institutions and Regional Development. W: R. Capello, P. Nijkamp (ed.), Handbook of Regional Growth and Development Theories. Cheltenham UK, Northampton, MA: Edward Elgar Publishing.

Lawson, C. (2000). Collective Learning, System Competences and Epistemically Significant Moments. W: D. Keeble, F. Wilkinson (ed.), High-technology Clusters, Networking and Collective Learning in Europe. Ashgate, 182-197.

Leonard, D., Sensiper, S. (1998). The Role of Tacit Knowledge in Group Innovation. California Management Review, 40(3), 112-132.

Liu, J. (2011). Institutional Thickness and Its Impact on Intra-firm and Inter-organisational Innovation Networks: A Comparative Case Study in China and Switzerland. Paper presented at the DIME Final Conference, 6-8 April 2011, Maastricht.

Lucas, R.E. (1988). On the Mechanics of Economic Development. Journal of Monetary Economics, 22(1), 3-42.

Lundvall, B. (1995). National Systems of Innovation - Towards a Theory of Innovation and Interactive Learning. London: Biddles Ltd.

Maeninig, W., Olschlager, M. (2011). Innovative Milieu and Regional Competitiveness: The Role of Associations and Chambers of Commerce and Industry in Germany. Regional Studies, 45(4), $441-452$.

Morgan, K. (2007). The Learning Region: Institutions, Innovation and Regional Renewal. Regional Studies, 41, 147-159.

Murray, C. (2005). Social Capital and Cooperation in Central and Eastern Europe - A Theoretical Perspective Abstract. Institutional Change in Agriculture and Natural Resources Discussion Papers, 0905.

Nauwelaers, C., Wintjes, R. (2003). Towards a New Paradigm for Innovation Policy?. W: B. Asheim, A. Isaksen, C. Nauvelaers, F. Toedling (ed.), Regional Innovation Policy for Small-Medium Enterprises. Cheltenham: Edward Elgar, 193-219.

Niosi, J. (2010). Building National and Regional Innovation Systems: Institutions for Economic Development. Cheltenham: Edward Elgar.

North, D.C. (1990). Institutions, Institutional Change and Economic Performance. Cambridge: Cambridge University Press.

Nowakowska, A. (2011). Regionalny wymiar procesów innowacji. Łódź: Wydawnictwo UŁ.

Oerlemans, L.A.G., Meeus, M.T.H., Boekema, F.W.M. (2001). Firm Clustering and Innovation: Determinants and Effects. Papers in Regional Science, 80, 337-356.

Panagiotis, A., Arvanitidis, P.A., Petrakos, G. (2011). Explaining Knowledge-Based Economic Growth in the World Economy. W: P. Nijkamp, J. Siedschlag (red.), Innovation, Growth and Competitiveness. Dynamic Regions in the Knowledge-Based World Economy. Berlin Heidelberg: Springer Verlag.

Pecqueur, B., Zimmermann, J.B. (ed.). (2004). Economie des proximities. Paris: Hermes Science Publications.

Perry-Smith, J.E. (2003). The Social Side of Creativity: A Static and Dynamic Social Network Perspective. The Academy of Management Review, 28(1), 89-106.

Porter, M.E. (1998). Clusters and Competition: New Agendas for Companies, Governments, and Institutions. W: M.E. Porter (ed.), On Competition. Cambridge Harvard: Business Review Books. Porter, M.E. (2003). The Economic Performance of Regions. Regional Studies, 37, 549-578.

Rainnie, A., Grobbelaar, M. (ed.). (2005). New Regionalism in Australia. Ashgate: Aldershot. 
Rallet, A., Torre, A. (ed.). (2007). Quelles proximities pour innover? Paris: L'Harmattan.

Ratti, R., Bramanti, A., Gordon, R. (ed.). (1997). The Dynamics of Innovative Regions: The GREMI Approach. Ashgate Publishing Limited.

Rodrigez-Pose, A. (2010). Do Institutions Matter for Regional Development? Working Papers Series in Economic and Social Sciences, 02.

Rodrik, D. (1999). Where Did All the Growth Go? External Shocks, Social Conflict and Growth Collapses. Journal of Economic Growth, 4(4), 385-412.

Rodrik, D. (2000). Institutions for High-quality Growth: What They are and How to Acquire Them. Studies in Comparative International Development, 35, 3-31.

Rodrik, D., Subramanian, F., Trebbi, F. (2004). Institutions Rule: The Primacy of Institutions Over Geography and Integration in Economic Development. Journal of Economic Growth, 9, 131-165.

Romer, P.M. (1986). Increasing Returns and Long-Run Growth. The Journal of Political Economy, 94(5), 1002-1037.

Shearmur, R., Bonnet, N. (2011), Does local technological innovation lead to local development? A policy perspective. Regional Science Policy\&Practice, 3(3), 249-270.

Solow, R. (1956). A Contribution to the Theory of Economic Growth. The Quarterly Journal of Economics, 70(1), 65-94.

Stachowiak, K. (2008). Czynniki instytucjonalne w budowaniu i funkcjonowaniu gospodarki opartej na wiedzy - przykład Finlandii. W: J.J. Parysek, T. Stryjakiewicz (red.), Region społeczno-ekonomiczny i rozwój regionalny. Poznań: Bogucki Wydawnictwo Naukowe, 121-151.

Storper, M., Venables, A. (2004). Buzz: Face-to-Face Contact and the Urban Economy. Journal of Economic Geography, 4(4).

Wiig, H., Wood, M. (1995). What Comprises a Regional Innovation System? - An Empirical Study. STEP Working Paper, 01.

Anna Golejewska, dr, Uniwersytet Gdański, Wydział Ekonomiczny, Katedra Ekonomiki Integracji Europejskiej.

Anna Golejewska jest pracownikiem Katedry Ekonomiki Integracji Europejskiej na Wydziale Ekonomicznym Uniwersytetu Gdańskiego. Prowadzi wykłady z szeroko rozumianej gospodarki i polityki regionalnej, w tym innowacyjnych regionów oraz systemu wdrażania funduszy strukturalnych Unii Europejskich w Polsce. Jest członkiem Zespołów Ekspertów oceniających projekty złożone w ramach Regionalnego Programu Operacyjnego Województwa Pomorskiego, Programu Operacyjnego Kapitał Ludzki oraz Programu Operacyjnego Innowacyjna Gospodarka 2007-2013. Autorka licznych publikacji poświęconych tematyce konkurencyjności. Członek Regional Studies Association.

Anna Golejewska, $\mathrm{PhD}$, is a member of the staff of the Chair of Economics of European Integration at the Faculty of Economics of Gdańsk University. She lectures on widely understood economy and regional policy, including the system of implementation of EU structural funds in Poland. She is a member of the Team of Experts assessing project applications under the Pomorskie Voivodeship Regional Operational Programme, the Human Capital Operational Programme and the Innovative Economy 2007-2013 Operational Programme. She has authored numerous publications devoted to competitiveness issues. She is a member of the Regional Studies Association.

adres/address: Uniwersytet Gdański, Wydział Ekonomiczny,

Katedra Ekonomiki Integracji Europejskiej,

ul. Armii Krajowej 119/121, 81-824 Sopot, Polska

e-mail: a.golejewska@ug.edu.pl 